\title{
Implementation of Solar Cell Based Smart Chair as a Green Open Space Electric Energy Source
}

\author{
Riklan Kango ${ }^{1}$, Hadiyanto ${ }^{1}$, Ezra Hartarto Pongtularan ${ }^{1}$, Mohamad Ilyas Abas ${ }^{2}$ \\ *Correspondence: riklan.kango@poltekba.ac.id \\ ${ }^{1}$ Politeknik Negeri Balikpapan, Indonesia \\ ${ }^{2}$ Universitas Muhammadiyah Gorontalo, Indonesia
}

\begin{abstract}
This research aims to propose new solutions for alternative sources of electrical energy in open spaces. We validated this solution by implementing a solar cell in a park bench object. Furthermore, analyzing the statistical data by taking the average value of; current, voltage, and power generated by the smart bench object. The experimental results show that the proposed solution has the same performance as conventional lighting. Electric park benches can operate longer using a solar cell with an output power of 26.76 Watt-peak hours. With the large potential of solar power, solar cells' application in an open environment is very suitable. With this electric bench, it is still energy efficient and green energy.
\end{abstract}

Keywords: Electrical Energy, Solar Cell, Smart Bench

Received : January 1, 2021

Revised: January 7, 2021

Accepted: January 12, 2021

\section{Introduction}

Energy problems that hit the world have implications for savings in all areas (Hadiyanto et al., 2020), including lighting for public spaces and furniture equipment (Frischer et al., 2020). However, lighting conventional public areas is an inaccurate step because the required monthly electricity costs are already costly. Renewable energy sources continue to be developed as an alternative energy source to substitute for the depleting fossil energy (Chen, 2020). One of them is a power plant with a solar cell that uses solar heat sources (Manikandan et al., 2018; Arif et al., 2019).

In this decade, the cost of installing and managing photovoltaic systems has been greatly reduced (Aromal et al., 2018). One of the implementations of solar cells (Photovoltaic) is electricity in public open spaces that require electricity (Artiani \& Siswoyo, 2019). The problem of providing a source of electricity for facilities in the park requires a budget of billions of rupiah (Eridani et al., 2020), and it still uses a lot of PLN (State Electricity Company) electricity so that if the electricity supply from PLN is cut off, there is no alternative source to replace it. So that it becomes a condition that causes an energy crisis (Hikmawan \& Suprayitno, 2018). So far, solar energy has only focused on garden lighting, with the system not yet integrated to regulate the electrical energy source automatically (Durganjali et al., 2020);(Hasan \& Husain, 2018)

Research authors Arif et al. have revealed that solar cells can convert solar energy into light energy used to produce lighting in open spaces during the day (Arif et al., 2019). Furthermore, research by Aromal, et al., Has designed an electric chair using solar cells. In this study, it has been revealed that solar cells can generate electric power for electric chair operations (Aromal et al., 2018). Meanwhile, research by G. P. Artiani and S. D. Siswoyo has optimized the green open space garden with renewable energy (Artiani \& Siswoyo, 2019). 
This research is a reference development, the manufacture of a park bench with photovoltaic power and implementing an automated lighting system and adding features of a mobile phone charging station.

This paper proposes a new solution based on the design technique and prototype of a powered park bench using a solar cell. The solution is used as an electricity source for LED lighting systems and mobile phone charging stations using Photovoltaics to save electrical energy. We try to develop this research to focus on adding the analysis of the power generated by solar cells to meet the electrical energy needs of each load. The solution is then tested in a public open space involving a charger station and LED lights in a park bench object.

This research has resulted in a bench prototype that has a power supply using a solar cell. The bench is designed to have an LED light facility designed to automatically turn on based on the intensity of the surrounding light. Another feature is that the bench has a mobile phone charging station to be used as an electricity source to charge a mobile device. This research makes a real contribution to energy conservation and saving the use of electrical energy in green open space parks. The remainder of this paper goes as follows: Section Method details the proposed smart bench system design. Section Results and Discussion presents empirical and experimental studies that evaluate the usefulness of the system. The experimental results obtained are analyzed and discussed in this section, as well. Finally, Section Conclusion and Suggestions presents concludes this paper.

\section{Methods}

This study discusses solar energy as an alternative source of electrical energy to operate an open space park bench. We propose to experiment with the output power of the solar cells measured under the conditions of the placement position (absorption angle) of the solar cell towards the fixed earth. Next, we describe the variables under study, current, voltage, and power, and we measure the illumination of solar radiation as is based on the variation in the time it takes (He et al., 2019). We carried measurements out on July 30, 2020, at Balikpapan City Three Generation Park in Figure 4.

We carried the data collection technique out by measuring using a digital AVO meter and Lux meter measuring equipment. We then include the measurement results in the experiment on the table (Khalis et al., 2016). Before measuring the environmental parameter variables, the first step is to make the physical structure and set-up of the solar cell electric bench by completing the electrical installation. The materials used are Polycrystalline Solar Panel 20WP 12v 1A, VRLA Battery 12V 18Ah, Step Down Regulator 12v to 9v, Solar Charger Controller 12 / 24v 10A, Arduino Uno DIP version, LCD 16X2 IIC, Relay Module 5VDC / 250VAC 10A, LDR Sensor, 12V 90mA LED strip. After the entire physical building of the solar-powered park bench is completed, we carry out the testing and measurement parameters needed in Figure 1. 


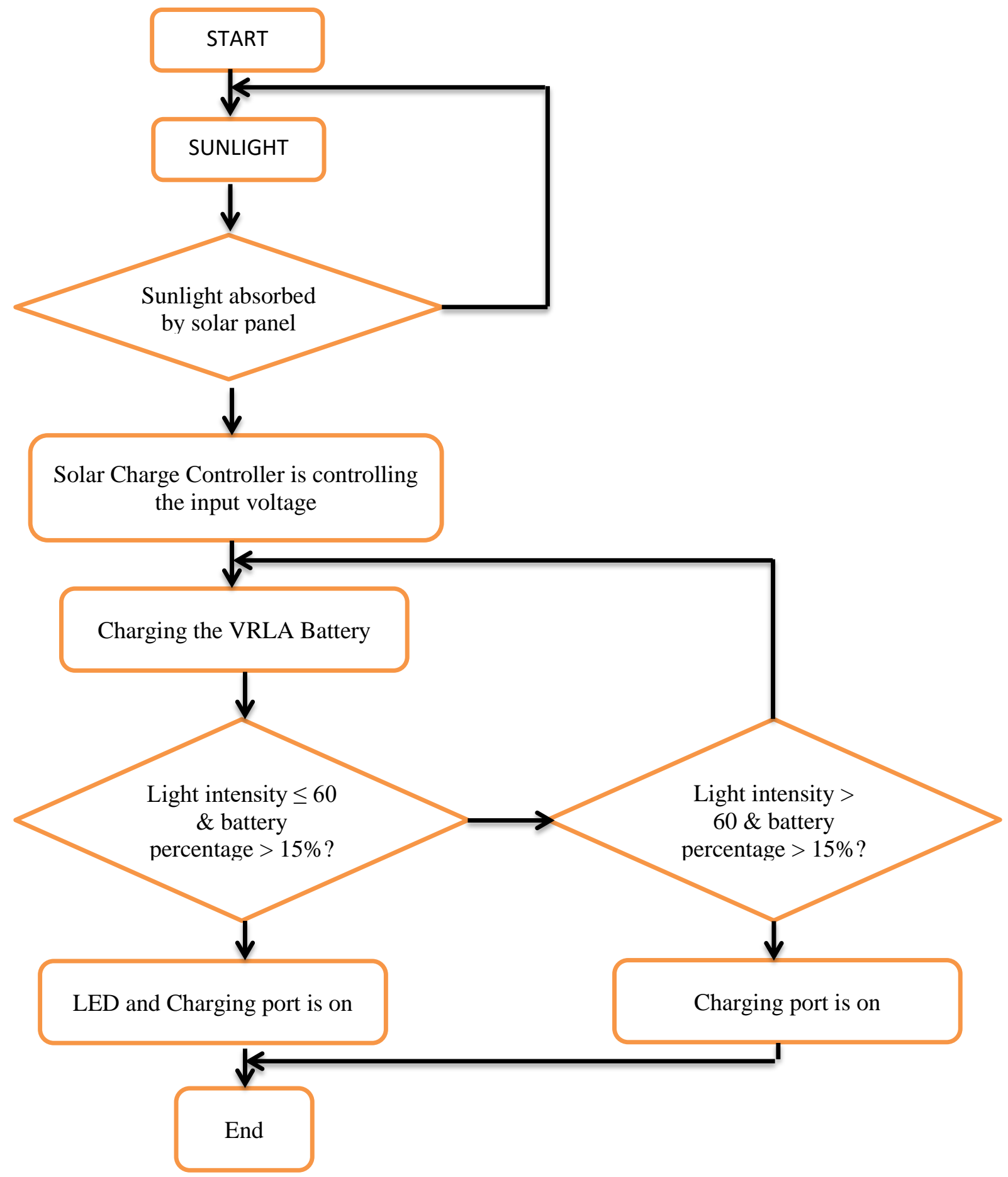

Figure 1. A flowchart diagram for our proposed method

We carry this data collection out every 10 minutes with the data taken in current and voltage and power generated. We get current and voltage values using a multimeter. Meanwhile, the power calculation uses the equation $\mathrm{P}=\mathrm{V} * \mathrm{I}$ (Aromal et al., 2018), and the Lux meter is used to determine the value of light intensity. In the form of tables and graphs, we analyzed all the data, then searched the experiment results for the average value for each parameter produced on park bench objects by the circuit system. 


\section{Results and Discussion}

The design of a park bench based on the solar cell in Figure 2 was designed using the Sketchup Pro 2020 application with the physical specifications for length $110 \mathrm{~cm}$, width 60 $\mathrm{cm}$, and height $55 \mathrm{~cm}$ with bench material made of iron. We store the electronic circuit Figure 3 under the solar panel in the middle and protects it using glass resistance to heavy pressure when people sit on the bench. Besides that, the electronic components are guaranteed to be sealed and safe from water when it rains. In the automation system, we use Arduino Uno to control the LED and USB output load in Figure 3. When the light intensity from the LDR sensor detects a value below 60 Lux, the light will automatically turn on by controlling the first Relay switch. When the battery is below 15\%, the charging features and light will automatically disconnect and cannot be used by controlling the second and first Relay. Features will be reusable when the battery is charged up to $30 \%$.

Table 1. Load simulation with Proteus 8

\begin{tabular}{|l|l|l|}
\hline & \multicolumn{1}{|c|}{ Battery > 15\% } & \multicolumn{1}{c|}{ Battery $\leq \mathbf{1 5 \%}$} \\
\hline Light $>60$ Lux & LED $=$ OFF & LED = OFF \\
& USB $=$ ON & USB = OFF \\
Light $\leq 60$ Lux & LED = ON & LED = OFF \\
& USB = ON & USB = OFF \\
\hline
\end{tabular}

Table 1 shows the simulation results of two loads that show the battery percentage is very influential, while the LED load is affected when the battery is sufficient, and the light is less than equal to 60 Lux. From our experimental results, our proposed method shows that the LED turns on when the light intensity is below 60 Lux and off when the light intensity is above 60 Lux, then the USB will function as a charge when the battery is above $15 \%$.

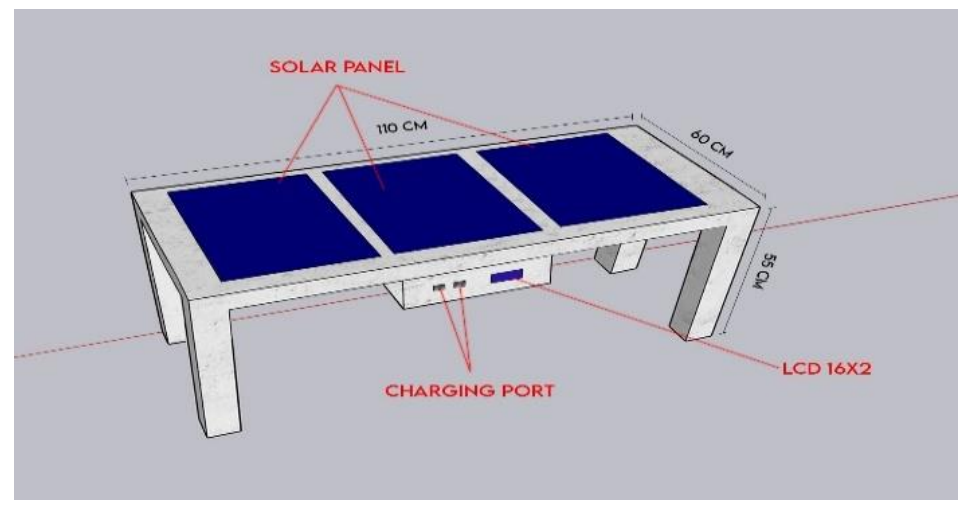

Figure 2. The front of smart bench

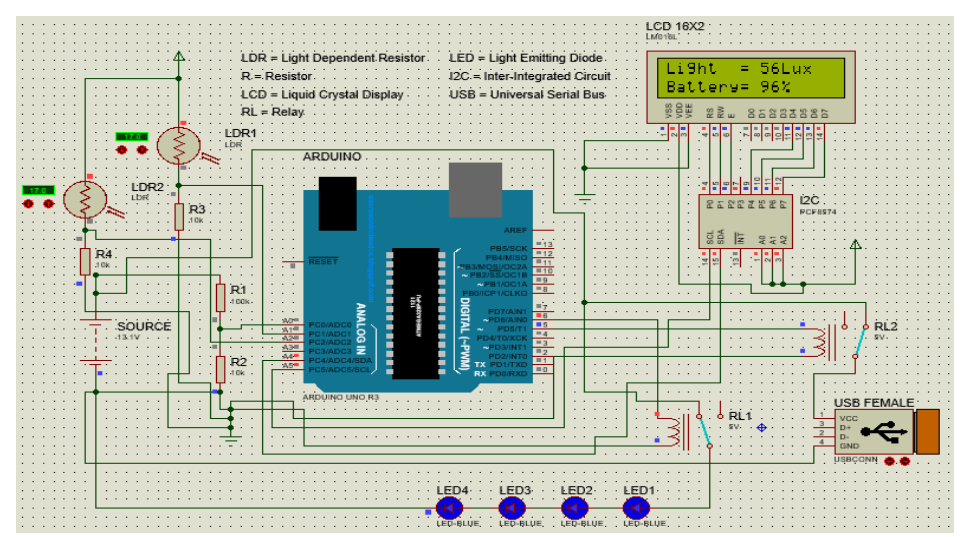

Figure 3. Diagram system of the smart bench 
Testing of park bench components is divided into two parts, namely solar panel testing and load circuit testing. We tested the solar cell performance in a park bench object for 1 hour by placing the object in the public space of Taman Tiga Generasi, Balikpapan City, in Figure 4. The first condition is during the day at 12:30 - 13:30, while the second condition is at 20:00 21:00. We collect current and voltage data every 10 minutes. The experiment results in Table 2 show that all solar cell circuits were functioning properly during the trial process. This shows that performing the solar cell circuit system works well to produce current and voltage in daytime conditions, but the performance is not optimal at night. While we get the Watt value using the equation $\mathrm{P}=\mathrm{V} * \mathrm{I}$ for each take, so that the average Watt for 1 hour of testing the object is got.

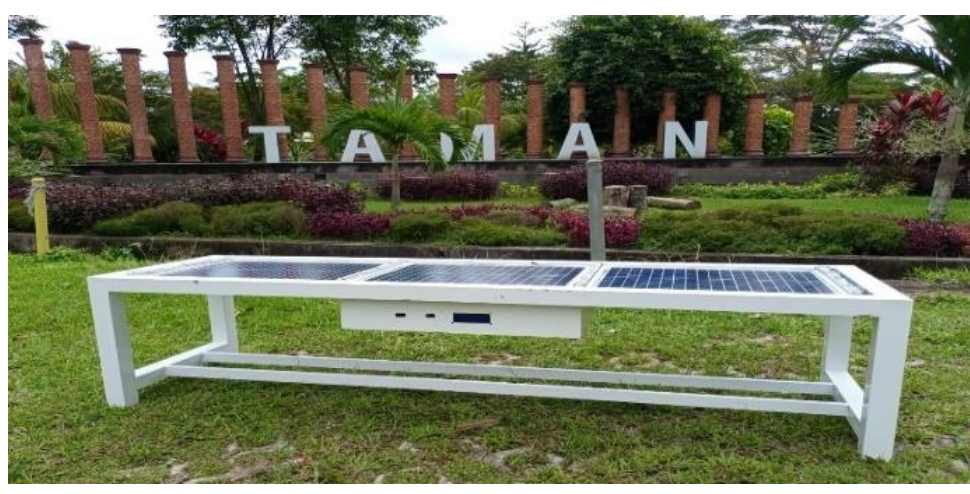

Figure 4. Object smart bench

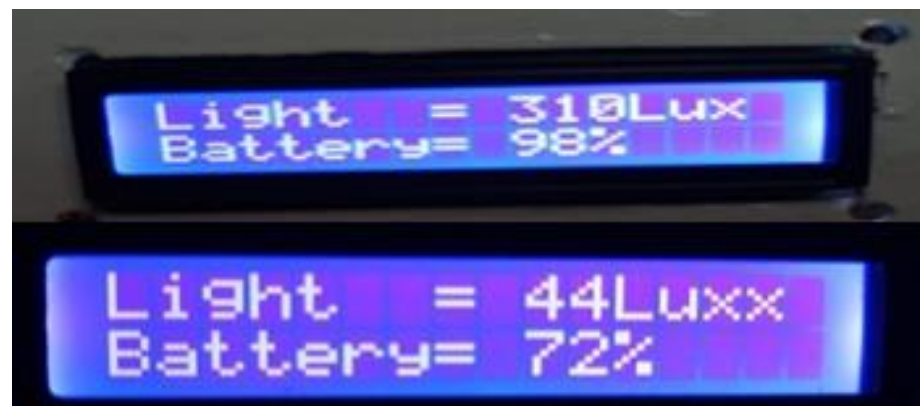

Figure 5. Part of the graphical user interface

Table 2 shows the performance of solar panels with optimal conditions achieved by obtaining current and voltage parameters. The results are shown to compare solar cell efficiency and battery charging characteristics as a source of electrical energy to the electrical system on the bench object. We carried our test out by connecting the solar charge controller with the 20 WP solar cell and two 12 Volt 18Ah batteries in series. The test results show the difference in Watts per time to take the efficiency value. The calculation result shows the highest value (12: 30-13: 30) for daytime conditions so that the solar cell can generate electrical power. These results are in line with the previous research that solar cells function optimally during the daytime.

Table 2. Performance of solar cell circuit

\begin{tabular}{|l|l|l|l|}
\hline \multicolumn{1}{|c|}{ Time Trial } & \multicolumn{1}{|c|}{$\begin{array}{c}\text { Average Voltage } \\
\text { value }\end{array}$} & \multicolumn{1}{c|}{$\begin{array}{c}\text { Average Current } \\
\text { Value }\end{array}$} & Watt \\
\hline $12: 30-13: 30$ & $13.57 \mathrm{~V}$ & $1.88 \mathrm{~A}$ & 26.76 \\
$20: 00-21: 00$ & $0.12 \mathrm{~V}$ & $0.01 \mathrm{~A}$ & 0.0001 \\
\hline
\end{tabular}

The implication of this study's results on saving electricity for public open spaces by integrating the object of open space facilities in this study is a park bench object. We use

Copyright (0) 2021, International Journal Papier Advance and Scientific Review, Under the license CC BY-SA 4.0

DOI: https://doi.org/10.47667/ijpasr.v2i1.64 
renewable energy sources through solar cells as an alternative energy source to replace dwindling fossil energy. The problem of providing a power source for facilities in the park has been resolved. So it becomes a situation that can increase the efficiency of electrical energy with the support of solar cell technology, which we integrate with the object of a park bench, which has a dual function, namely as a source of electricity for automated lighting.

Finally, we tested the entire set of park bench objects during the day and night for 1 hour each to find the effectiveness of solar panel charging and the condition of the object's features. The test results are presented in Tables 3 and 4, respectively.

Table 3. Performance of the smart bench during the day (12:00 - 13:00) pm

\begin{tabular}{|c|c|c|c|c|c|c|}
\hline No & $\begin{array}{c}\text { Time } \\
\text { Trial }\end{array}$ & Voltage & Current & $\begin{array}{c}\text { Battery } \\
\text { percentage }\end{array}$ & $\begin{array}{c}\text { Condition } \\
\text { LED }\end{array}$ & $\begin{array}{c}\text { Condition } \\
\text { Charger }\end{array}$ \\
\hline 1 & $12: 00$ & 13.3 & 0.9 & 98 & OFF & ON \\
2 & $12: 10$ & 13.3 & 0.9 & 98 & OFF & ON \\
3 & $12: 20$ & 13.4 & 0.91 & 98 & OFF & ON \\
4 & $12: 30$ & 13.4 & 0.92 & 98 & OFF & ON \\
5 & $12: 40$ & 13.4 & 0.93 & 98 & OFF & ON \\
6 & $12: 50$ & 13.4 & 0.93 & 98 & OFF & ON \\
7 & $13: 00$ & 13.4 & 0.93 & 99 & OFF & ON \\
\hline
\end{tabular}

Table 4. Performance of the smart bench at night (20:00-19.00) pm

\begin{tabular}{|c|c|c|c|c|c|c|}
\hline No & $\begin{array}{c}\text { Time } \\
\text { Trial }\end{array}$ & Voltage & Current & $\begin{array}{c}\text { Battery } \\
\text { percentage }\end{array}$ & $\begin{array}{c}\text { Condition } \\
\text { LED }\end{array}$ & $\begin{array}{c}\text { Condition } \\
\text { Charger }\end{array}$ \\
\hline 1 & $19: 00$ & 0.1 & 0.01 & 72 & ON & ON \\
2 & $19: 10$ & 0.1 & 0.01 & 72 & ON & ON \\
3 & $19: 20$ & 0.1 & 0.01 & 72 & ON & ON \\
4 & $19: 30$ & 0.1 & 0.01 & 71 & ON & ON \\
5 & $19: 40$ & 0.1 & 0.01 & 71 & ON & ON \\
6 & $19: 50$ & 0.1 & 0.01 & 71 & ON & ON \\
7 & $20: 00$ & 0.1 & 0.013 & 71 & ON & ON \\
\hline
\end{tabular}

Tables 3 and 4 show that the voltage and current at night are very inefficient for charging solar panels compared to during the day. Our experiments show that the LED works in dark lighting conditions only. In comparison, the charged condition will continue to function if the battery is above $15 \%$. This can apply to the drastic changes in day and night lighting. However, changing this condition will not cause much error when this park bench is applied. The test results also got light intensity for daytime and nighttime conditions in Figure 3 . This shows the light sensor on the object is functioning in Figure 5. The current and voltage values show that the solar cell is stable at low or high threshold values. Thus, the proposed park bench can handle different lighting conditions to function within a reasonable range as a dual function object.

\section{Conclusion}

This paper presents the basic energy sources needed for making garden benches based on solar cell electricity as a source of electricity in open spaces. The bench model with solar cell electricity was created for modification as well as independent manufacture. We demonstrated the importance of making garden benches with solar cell electricity to recognize renewable power capabilities. The experimental results show that the load on the solar cell electric bench depends on the battery's percentage in the automatic system. We make garden benches out of aluminum to support electronics (cables, sensors, etc.). Besides, we combined the charger station with a bench to obtain objects that play a dual role. We 
could achieve our goal of building a portable park bench that can act as a charging station. Further work could be done on improving the improved bench resistance test method to identify areas for improvement, the use of solar panels with larger peak wattages.

\section{Acknowledgments}

The author would like to thank the Balikpapan City Housing and Settlement Office, Indonesia, for financial support to implement research products. The author also thanks Balikpapan State Polytechnic for financial support through the program (Competitive Research), the driving force for this research.

\section{References}

Arif, E. M. H., Hossen, J., Ramana Murthy, G., Jesmeen, M. Z. H., \& Emerson Raja, J. (2019). An efficient microcontroller based sun tracker control for solar cell systems. International Journal of Electrical and Computer Engineering, 9(4), 2743-2750. https://doi.org/10.11591/ijece.v9i4.pp2743-2750

Aromal, V., Gokulnath, G. L., Amrithesh, M. S., Arun, B., Varma, A. P. K., \& Pandi, V. R. (2018). Design and Implementation of a Solar Integration in Electric Wheelchair. 2018 4th International Conference for Convergence in Technology, I2CT 2018, 1-6. https://doi.org/10.1109/I2CT42659.2018.9058203

Artiani, G. P., \& Siswoyo, S. D. (2019). Optimalisasi Ruang Terbuka Hijau Berupa Taman Energi Baru Terbarukan Sebagai Upaya Pemanfaatan Lahan Kosong Di Lingkungan Kampus (Studi Kasus Kampus Stt-Pln, Jakarta). Jurnal Konstruksia, 11, 1-10.

Chen, Q. (2020). The King of the New Generation Photovoltaic Technologies_-Perovskite Solar Cells \& the Opportunities and Challenges. IOP Conference Series: Materials Science and Engineering, 926, 012010. https://doi.org/10.1088/1757$899 x / 926 / 1 / 012010$

Durganjali, C. S., Bethanabhotla, S., Kasina, S., \& Radhika, D. S. (2020). Recent Developments and Future Advancements in Solar Panels Technology. Journal of Physics: Conference Series, 1495(1). https://doi.org/10.1088/1742$6596 / 1495 / 1 / 012018$

Eridani, D., Asyauqqi, M. A., \& Prasetijo, A. B. (2020). Analisis Purwarupa Sistem Otomatisasi Penerang Jalan Untuk Menghemat Daya Listrik. Jurnal Sains Komputer \& Informatika, 4, 142-156.

Frischer, R., Krejcar, O., Maresova, P., Fadeyi, O., Selamat, A., Kuca, K., Tomsone, S., Teixeira, J. P., Madureira, J., \& Melero, F. J. (2020). Commercial ICT smart solutions for the elderly: State of the art and future challenges in the smart furniture sector. Electronics (Switzerland), 9(1). https://doi.org/10.3390/electronics9010149

Hadiyanto, H., Suheidi, S., \& Kango, R. (2020). Evaluasi Intensitas Konsumsi Energi Listrik Di Kampus Politeknik Negeri Balikpapan. JST (Jurnal Sains Terapan), 6(1), 1-7. https://doi.org/10.32487/jst.v6i1.832

Hasan, A. B., \& Husain, S. A. (2018). Design of Light Trapping Solar Cell System by Using Zemax Program. Journal of Physics: Conference Series, 1003(1). https://doi.org/10.1088/1742-6596/1003/1/012074

He, Y. T., Xiao, L. X., Wang, F. Y., \& Wang, J. Q. (2019). Design and experimental study of thermal storage PV/T/PCM solar collector. IOP Conference Series: Earth and 
Environmental Science, 354(1). https://doi.org/10.1088/1755-1315/354/1/012014

Hikmawan, S. R., \& Suprayitno, E. A. (2018). Rancang Bangun Lampu Penerangan Jalan Umum (Pju) Menggunakan Solar Panel Berbasis Android (Aplikasi Di Jalan Parkiran Kampus 2 Umsida). Elinvo (Electronics, Informatics, and Vocational Education), 3(1), 9-17. https://doi.org/10.21831/elinvo.v3i1.15343

Khalis, M., Masrour, R., Khrypunov, G., Kirichenko, M., Kudiy, D., \& Zazoui, M. (2016). Effects of Temperature and Concentration Mono and Polycrystalline Silicon Solar Cells: Extraction Parameters. Journal of Physics: Conference Series, 758(1). https://doi.org/10.1088/1742-6596/758/1/012001

Manikandan, P., Karthick, S., Saravanan, S., \& Divya, T. (2018). Role of Solar Powered Automatic Traffic Light Controller for Energy Conservation. International Research Journal of Engineering and Technology, 05(12), 989-992. 